\title{
Engineering Geophysics - A New Concept
}

\author{
A. E. SCHEIDFGGER * \\ Received on October 3rd, 1972
}

\begin{abstract}
Sexuary. -.. In analogy to "enginesring physics", "engineering geophysies" is defined as the enginering applieations of geophysieal phenomena. These incluce processes ocenring anywhere from the Earth's core to the upper atmosphere: thus, there is a vast range of possible applications. In this paper a disenssion is given of engineering applieations of the playsies of the solid Earth (including seismology, voleamology and geomechanies), of the physies of the hylresplere (ineluding hydrology) and of the physies of the atmosphere (including tornatocs and lightning).
\end{abstract}

Riassunto. - Analoganente al termine "fisiea ingegucristica", "geofisiea ingegneristiea" si definisce come applicazione all'ingegneria di fenomeni geofisici. Questi comprentono i processi che arvengono in un yualumyue punto dal nucleo ilella Terra all alta armosfera; li qui l'enorme campo di possibili applieazioni. In questo lavoro vieue fatta una disenssione sull ap. plicazione all'ingegneria della fisiea tella T'erra oolida (eomprendente sismologia vulcanologia e geomeceniea), della fisiea dellidrosfera (includendo l'ilrologia) e infine della fisica dell'atmosfora (includente i tornatu e i fulmini).

\section{1. - Intronuction.}

If one translates the word "geophysics" from Greek into linglish, it signifies "the nature of the Earth". Neant is of comrse the study of the nature of the Earth. In the molern comnotation, the word "physies" does not mean "nature" in general any more, lout the workings of the materials involved excluding changes in composition.

* Technische I[ochscluule Wien, Justitut für Goplıysik A - 1040 Wien Karlsplatz 13, Austria. 
By its refinition, "geoplyysios" is therefore the sturly of the physies of the Farth. Commonly, this inclucles now the gamut from the Earth's core to the solar-terrestrial relationships. Applications of geophysies to the economic field have, thus far, mostly been eonfinel to geophysieal exploration. It is elear, however, that these applications could be vastly extendeci, inasmuch as many aspects of geopliysies lend themselves to engineering uses. In aralogy with "engineering pliysies", I like to rlesignate the systematic sturly of engineering applications of geophysies as "engincering geophysics". Some engineering applications of geoplyysics are, of course, well known, such as engineering seismology, but on the whole, geophysies has not as systematically been applied to engineering as it might have been.

In this paper, I only plan to discuss some of the engineering applications of geoplissics that might be useful in practical work. To grive a comprehensive review would be quite impossible as the subject is vast.

The physies of the Farth is commonly divided into the ploysies of the solid eartil, the physies of the hychosphere and the pliysies of the atmosplere. In what follows, I will keep the same division.

\section{2. - EXgINEERING GEOPIIYSICS OF THE SOLID EARTI}

For man, the surface of the solid earth is probably the most important region of the Iniverse becmuse he lives thereon. In this connection, the fast or slow changes of this surface are of paticulaw signiticance, since they represent an alteration in lis labitat. These chunges are generally caused by "geo"-plyysical proeesses within and without the Earth.

Frast ahanges can oecul as veritable catastrophes. Slow changes, however, an be just as serious altilongl tiley may lack the particularly spectacular aspects of a sukdenly occurring disuster.

If one thinks of rlisasters, some of the most fearerl ones atre earthquakes. Farthquakes are shocks that usually oecur without warning; they rngender sudden displacements on the Earth's surface that can cause builkings to rollapse. The stukly of eartlipuakes is culled "seismology"; "engineering seismology" is one of the few branches of engineering geophysies which has alrearly received some attention. Thus far, what triggers an eartliquake is not known. It laas been found that 
earthquakes cluster spacially in certain regions fnotably the eirrumPacific belt), but what actualy causes an earthquake to occur, is not known. Thus, the general seismie risk ran be determinel for a certain area, but a prediction of earthquakes has not yet been achieved. Incisientally, this is a rather "hot" subject just now.

Warthquakes are georlynamic phenomena; i.e. phenomena basically caused by processes taking place in the Earth's interior. Of a similar origin are volcanic emptions. Such eruptions have eaused spectacular disasters in historical times; one need only think of the disasters at Herculaneum and Pompeii and of AIt. Pelie. Thus, many countries could make good engineering use of geophysical observations on voleanoes and from an understanding of their meclanism.

of lireet applicability to engineering are geophysical events occuring quite generally on "slopes". I mean any kind of slopes: excatvations, mountain sirles, embankments ete. Questions of the stability of such slojes have been studieal extensively by civil engineers: the geophysicist, however, wishes to go further, inasmuch as the entire physies of the motion, inclusling the physies of the very collapse, is of interest to him. Contrariwise, the engineer is not concerned with the latter, because his main aim is to prevent such an occurrence. Nevertheless, the mechanies of a landslide, if known, could also be put to engineering use, e.g. for the evaluation of the safety of a site or in the design of protective measures. Stability estimates on slopes often depend on a knowledge of the plyysics of a potential slide. Strangely enough, the physios of a major slide is still largely a matter of speculation. The ordinary friction between the rocks is simply too great for a major slike to occur at all. One stands here before a great puzale. Famous cases are the slides at Frank, Alberta in 1903 und the slide at Vajont in Upper ftaly in 1963. The latter was a particularly disastrous event. A dam was built aross a leep valley to ereate a lake behind it for a hylroelectric power levelopment. When the lake was lilling up, the pore pressure rise caused thereby apparently made one of the slopes unstable. It started to creep: - this in itself was no catuse of concern to the engineers, because all slopes creep everywhere anyway. The creeping motion accelerated eventually to 20 centimeters pir day on the daty before the catastroplie, but noboly forsaw the disaster that then followed inside of a short time: 200 million cubic meters of rock material slid into the lake, with a velocity of about $25 \mathrm{~m} / \mathrm{sec}$, eausing a tremendous floodwave (the dam hell!) to spill into the valley below with a death toll of some 2000 people. 
Similarly large speeds have been observed in otlier catastrophic land slides. By all stanclard physical theory, such ovents should be meclanically impossible. The sliding surfaces are not steep, perhaps around $20^{\circ}$, well below the angle of repose of the material in question and tlie rock friction slould canse any moving mass to stop ratlier quickly. How then can the almost total loss of friction be explained? Pore water pressure and thixotropy has certainly sometling to do with it, but alone it is hardly sufficient to reduce the friction to almost zero. The latest conjectures are that the slide moves on an air or steam cushion, perhaps caused by the evaporation of the pore water due to the heat created by the initial friction. The accurate following up of sucl conjectures is, lowever, a difficult thermodynamis problem which has by no means been solved. Evidently, the simple laws of mechanies are no longer sufficient and other ficlds of physies, like thermodynamics, have to be introduced.

Who was at fault in the Fajont disaster? The engineer's can liarlly be blamed, because tlie event conla not be foreseen. \#оwever, a bit more "engincering geophysical" research of the behavior (and not just of the stability) of slopes before the event might have provided the insight that could lakre given the engineers the means to foresee the possible implications of his actions, and to molifyis designs accordingly.

Great disasters with many casnalties tend to make news, because they are spectacular. Minor events, like rock falls, the motions of single boulders down a slope etc. are just as serious for those affected by it as a great disaster to the victims of it. $\Lambda$ motorist killed by a rook rolling onto the highway is just as dead as any of those people killed by the Vajont flood wave, although he will scarcely make the papers. Similarly, many slow phenomena may not cause deatli, but great porperty damage. One only has to think of the city of Venice sinking into the sea. As noted above, all slopes creep, with sometimes serions eflects on bridge abutments cte. Much of the mechanics of suel events is only imperfectly known, in spite of many stullies by civil engineers.

\section{3. - GingtNefrivg GeOHHYSICS OF TIIE IIYDROSPHERE}

Engineering applications of lydrology are numerous. I only need to recall the pliysics of flow through porous meilia with its application to groundwater studies. In the undersaturated zone, again not 
only mechanies, but also themorlyuamies and the molecular behavionr of air and moisture has to be used.

As on the solici earth, the hyclrosphere also maty give rise to spectacular disasters: floodwaves, tidal waves, tsunamis. Such events lead to difficult mathematical problems, since all the differential equations are 10 linear.

Floorls may oceur by a combination of meteorological conclitions. Attempts have been male to predict the occurrence of such ljoods. Thus far, only statistical prognostications can be marle. One treats the "hydrograph", that is the temporal sequence of water level readings, as a "time series". The statistical properties of such time series can be analysed and describet. From this, preslictions of the general frequency of the oceurrence of a particular size floorl, if not the time thereof, can be marle.

Less spectacular, but of great importance, is the mechanies of erosion: the near-shore cireulation system on a coast is respousible for the evolution of beaches etc, meanders create river terraces, and gullying the ilegratation of a slopee.

Glaciers are also part of the liytrospluere. For engineering purposes, they have recently gained more and more importance, bectuse developments are pushed to the limits of the liabitable areas. Thus, near Mattmark in the Canton of Wallis in Switzerland, a workman's eamp (in comnection with the building of a (am) was located below a glacier. One afternoon in 1965 a large mass of ice, 1.6 to $2.0 \cdot 10^{8} \mathrm{~m}^{3}$, broke ofl that glacier and killed 88 men. An unexpected "surge" in the ice had taken place which led to the break-off when it reached the glacier tongue. Needless to say, the accident gave some impotus to the sturly of the thermorlynamies of glacier surges; but this was like locking the barn aiter the horse laul been stolen.

Many more examples of engineoring glaciology and engineering hydrology could be cited, but the above will have to suffice.

\section{4. - ENGINFERING GEOPIIYSICS OF THE $\Lambda$ TAOSPHERE.}

Finally, a few worls albont the pliyrsies of the atmospliere. Engincering applications thereof are mostly concerned with wind stress. The wind stress can be substantial, as is evidenced by the destruction cunsed by tornidoes. Anch research needs still to be done to understand this phenomenon, to predict it and to arrive at flesign criteria for 
constructing houses wich will not collapse when hit by a torudo. Up to the present, very little is done in this regard. In tormado arens, one simply trusts God. Perlans one has proceeded to provide a warning system of imminent tormarloes, but this is not of too much use if one does not really lave a safe place in an ordinarily built house to go to.

$T_{11}$ connection with atmosplieric plenomena, one sliould also mention the plifsics of lightining as possibly lealing to some engineering applications for the protection of lives and property. One night perhaps think that lightning causes only minor distress, but at the end of August 1972, an oil tanker blew up when struck. MIuch minor damage is also chused by lightning which reflects itself in insurance rates and such like.

\section{5. - CoxClysion}

The above remarks were intended to present a few typical applications of geoplysies to engineering problems. I like to call this "engineering geoplyysics". Tle engincer needs to know the basic pliysics of the phenomena oceuring on the Fartl's surface with which he has to deal. The required values of the expected stresses, frequencies, velocities etc. can be provided by the geoplyysicist who, as a fundamental scientist, is perhaps best qualified to study the pertinent plienomena por se without being under the pressure to finish job after job. 